\title{
Peertechz
}

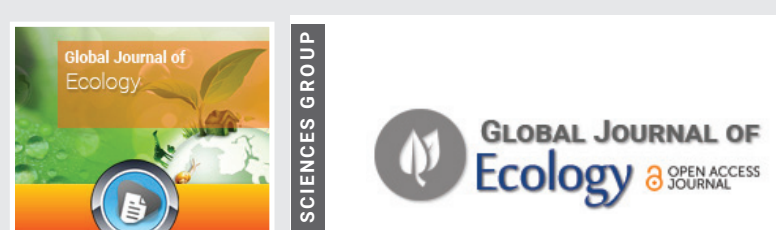

\section{Genetic Engineering in the Twenty-First Century: Genetically modified organisms}

\section{Conrad B Quintyn*}

Associate Professor, Department of Anthropology, Bloomsburg University, United States
Received: 22 September, 2021

Accepted: 01 October, 2021

Published: 05 October, 2021

*Corresponding author: Conrad B Quintyn, PhD, Associate Professor, Associate Professor, Department of Anthropology, Bloomsburg University, United States, Tel: 570-389-5379; Fax: 570-389-5015

E-mail: cquintyn@bloomu.edu

\section{ORCID: https://orcid.org/0000-0002-5903-9538}

Copyright: (c) 2021 Quintyn CB. This is an openaccess article distributed under the terms of the Creative Commons Attribution License, which permits unrestricted use, distribution, and reproduction in any medium, provided the original author and source are credited.

https://www.peertechzpublications.com
In agriculture, animals and plants are engineered to produce pharmaceuticals, and crops are modified to be nutritious, tolerant of herbicides and the natural environment, and resistant to disease. While these goals may seem practical, is it wise to modify plant systems without a clear idea of the longterm effects of genetic engineering in animals and humans? [1]. Are pharmaceutical companies in a race to increase their profits in the relatively new market of biopharming? If so, these companies are just responding to the pressures of a capitalist system, but what is the long-term risk? Before considering these questions, first consider some examples of current technology.

\section{Transgenic crops}

Tomato, tobacco, and soybean plants are infected by the bacterium Agrobacterium tumefaciens using its tumor-inducing plasmid [2]. How can biologists alter the characteristics of these plants? They isolate a tumor-preventing gene from the DNA of another organism and insert it into the plasmid [3]. The plasmid is then returned to the Agrobacterium. When Agrobacterium infects a plant, the new tumor-preventing gene is transferred into a chromosome of the plant cell.

Glyphosate is a powerful herbicide that kills most actively growing plants by inhibiting an enzyme called 5-enolpyruvylshikimate-3-phosphate (EPSP) synthetase, which plants need to produce aromatic amino acids [4]. Extra copies of the EPSP synthetase gene are inserted into plants via tumor-inducing plasmid. Subsequently, these new transgenic plants produce more than the normal level of EPSP synthetase and are glyphosate resistant.
At present, corn, cotton, soybeans, and canola have been genetically engineered to be glyphosate resistant [4]. These modified crop plants are popularly known as genetically modified (GM) plants, and glyphosate-resistant soybeans are grown in nine countries [5]. In fact, 90 percent of soybeans grown in the United States are GM soy. Historically, Western countries have taken steps to protect the public from scientific research. However, in this new frontier of genetic engineering, and GM crops in particular, US biologists are moving quickly and somewhat recklessly. Interestingly, their speed in creating transgenic plants is similar to that of biologists in Asia who have generated the largest growth of GM crops in an environment of limited safety regulations [5]. In contrast, European governments are being more cautious about GM crops [6].

Biologists have also engineered staple crops to express key vitamins and minerals. For example, they genetically modified rice to produce $\beta$-carotene (provitamin $\mathrm{A}$ ), which gives the engineered rice a golden color in the outer layer or endosperm $[7,8]$. This GM rice is possible because rice generates a precursor, geranylgeranyl diphosphate, in the endosperm tissue, which can be converted by three enzymes (phytoene synthase, phytoene desaturase, and lycopene $\beta$-cyclase) to $\beta$-carotene [7]. Genes for these three enzymes were introduced into the rice genome to allow expression of the pathway producing $\beta$-carotene in the endosperm. Using the gene for phytoene synthase from maize (instead of the original daffodil gene) leads to even higher levels of $\beta$-carotene. In essence, this so-called Golden Rice provides provitamin A in the diet, which enzymes in the human body can convert to vitamin A [8]. Deficiency in this vitamin affects preschool children worldwide [9]. 


\section{Biopharmaceuticals crops}

Insects feast on many commercially important plants, which costs billions of dollars each year. The usual defense against such feasts is to apply insecticides. However, within several generations, insects become resistant. In addition, chemical and pharmaceutical companies do not produce large stocks of insecticides because they are expensive to make, and the demand is small [10]. At present, the targets of more than half of all insecticides used are boll weevils, bollworms, and other insects that eat cotton. As a result, biologists have engineered plants that are resistant to insects.

Obviously, any engineered gene must be harmful only to the targeted organisms-boll weevils and bollworms, for example-and not other organisms. This is the source of longterm uncertainty. Nevertheless, genes for the Bt toxin produced by the soil bacterium Bacillus thuringiensis have been introduced in crop plants [11]. When insects ingest the engineered crop plants, Bt toxin enters their systems [12]. For the insects, irreversible cascading events of paralysis and death occurs as their endogenous enzymes convert Bt toxin into an insectspecific toxin. It is absolutely critical that these enzymes are not found in humans or animals; otherwise consumption of these GM crops would be catastrophic. Fortunately, the global distribution of Bt crops is similar to the distribution of herbicide-resistant crops. Bt corn is the second most common GM crop, representing 14 percent of the global area of GM crops in nine countries [11].

\section{Genetically modified organisms versus genetic editing}

At this point, CRISPR/Cas9 enters the conversation, because biochemist and 2020 Nobel laureate Jennifer Doudna, professor in the molecular and cell biology departments at the University of California, Berkeley, and one of the discoverers of the CRISPR/Cas9 technology, makes a distinction between GMOs and gene-edited organisms [13]. European governments have made a similar distinction as they struggle to fit genetic editing into their current regulatory framework, which was designed for GMOs. Doudna stated:

Conventional GMOs contain foreign genes randomly inserted into the genome; these genes produce novel proteins that give the organism a beneficial trait it did not previously possess. Gene-edited organisms, by contrast, contain tiny alterations to existing genes that give the organism a beneficial trait by tweaking the levels of proteins that were already there to begin with-without adding any foreign DNA. In this respect, gene-edited organisms are often no different than those organisms produced by mutation-inducing chemicals and radiation. Furthermore, scientists have used methods to avoid leaving any traces of CRISPR in plant genome once the gene-editing task is complete [14].

But members of the public clearly neither are educated enough in molecular genetics nor have the patience for the fine distinctions of scientists; they feel that "the gene-edited crops are nothing but hidden GMOs and that scientists are trying to sneak them into grocery stores through the back door " [15].
Nevertheless, CRISPR has been used to edit genes in rice and oranges to make them resistant to different bacterial species [16]. For potatoes, corn, and soybeans, genes have been edited so that they have resistance to herbicides. Additionally, Doudna noted that potatoes have been edited to inactivate a gene that produces sugars such as glucose and fructose (produced during cold storage preservation and converted to acrylamide, a neurotoxin, during cooking); soybeans have been edited to generate seeds with less fatty acids; and mushrooms have been edited to prevent premature spoiling.

The distinction between GMOs and gene-edited organisms seems specious; there is one common fact: humans are genetically modifying nonhuman species. To date, GM and gene-edited crops have not caused any major medical issues [17]. But what are the potential long-term evolutionary biological changes for humans, animals, and plants? Environmental scientist Maywa Montenegro in the Department of Environmental Science at the University of California, Berkeley, noted the emphasis on genes and their effects as separate from the environmental context. She wrote:

In what scholar Donna Haraway calls the "god-trick," we thought of genetics as the key to scientific mastery of nature, as if there was no context, no agency in the object, no imperfection in human knowledge. Molecular science somehow licensed us to treat genes as separate from ecology and bodies. Now we fathoming intricate interactions between genes and environments, and ecosystems whose changes aren't smooth or predictable, but that bristle with threshold effects and emergent properties. We've come to appreciate the inseparability of nature and culture in complex systems [18]. (italics added)

In short, molecular scientists consumed by "correcting" nature forget about the complex bioenvironmental interactions. There is now fear that after a particular genetic modification, modified genes might spread to wild relatives through a process called introgression, leading to biodiversity loss and extinction (gene drive mechanisms in the wrong hands might do the same) [19]. Also, there is a good chance that the engineered gene could trigger an allergic reaction based on the genetics of the individual consuming a product derived from it. Despite these concerns, some beneficial human proteins have been produced in genetically engineered plants.

\section{References}

1. Devos $Y$, Maeseele P, Reheut $D$, van Speybroeck L, De Waele D (2007) Ethics in the societal debate on genetically modified organisms: A (re)quest for sense and sensibility. Journal of Agricultural and Environmental Ethics 21: 29-61. Link: https://bit.ly/3IOPDwN

2. Raven P, Johnson GB, Mason KA, Losos JB, Singer SR (2008) Biology. 9th ed (New York: McGraw-Hill, 2008) 346. Link: https://bit.ly/3m9Q4UK

3. Ibid 345 .

4. Ibid 346-347

5. Ibid.

6. Demont M, Dillen K, Mathiis E, Tollens E (2007) GM crops in Europe: How much value and for whom?. Euro Choices 6: 46-53. Link: https://bit.ly/2Y1FC9s 
7. Lambers H, Brundrett MC, Raven JA, Hopper SD (2011) Plant mineral nutrition in ancient landscapes: high plant species diversity on infertile soils is linked to functional diversity for nutritional strategies. 348: 7. Link: https://bit.ly/3mngFhd

8. Beyer P, Al-Babili $S, Y e X$, Lucca $P$, Schaub $P$, et al. (2002) Golden rice: Introducing the $\beta$-carotene biosynthesis pathway into rice endosperm by genetic engineering to defeat vitamin A deficiency. J Nutr 132: 506S-510S. Link: https://bit.ly/3uC6aKM

9. Ibid. 348 .

10. Potrykus I (2012) Golden Rice", a GMO-product for public good, and the consequences of GE-regulation. Journal of Plant Biochemistry and Biotechnology 21: 68-75. Link: https://bit.ly/3kYut2k

11. Raven, et al. Biology 347.

12. Sears MK, Hellmich RL, Stanley-Horn DE, Oberhauser KS, Pleasants JM, et al. (2001) Impact of Bt corn on monarch butterfly populations: A risk assessment. Proceedings of the National Academy of Sciences 98: 1193711942. Link: https://bit.ly/3zYcFbU
13. Doudna JA, Sternberg SH (2017) A Crack in Creation: Gene Editing and the Unthinkable Power to Control Evolution (New York: Houghton Mifflin Harcourt, 2017) 125-126. Link: https://bit.ly/2ZHqQp3

14. Ibid. 127.

15. Ibid. 124

16. Shew AM, Nalley L L, Snell HA, Nayga RM, Nixon BL (2018) CRISPR versus GMOs: Public acceptance and valuation. Global Food Security 19: 71-80. Link: https://bit.ly/2ZOGxLp

17. Stokstad E (2018) European court ruiling raises hurdles for CRISPR crops Science. Link: https://bit.ly/3zZ4vQg

18. Montenegro M (2016) CRISPR Is Coming to Agriculture-With Big Implications for Food, Farmers, Consumers and Nature. Link: https://bit.ly/3zYV6Z2

19. Spurgeon D (2001) Call for tighter controls on transgenic foods. Nature 409 749. Link: https://bit.ly/3D5CgRR

\section{Discover a bigger Impact and Visibility of your article publication with}

\section{Peertechz Publications}

\section{Highlights}

* Signatory publisher of ORCID

* Signatory Publisher of DORA (San Francisco Declaration on Research Assessment)

* Articles archived in worlds' renowned service providers such as Portico, CNKI, AGRIS, TDNet, Base (Bielefeld University Library), CrossRef, Scilit, J-Gate etc.

* Journals indexed in ICMJE, SHERPA/ROMEO, Google Scholar etc.

* OAI-PMH (Open Archives Initiative Protocol for Metadata Harvesting)

* Dedicated Editorial Board for every journa

* Accurate and rapid peer-review process

* Increased citations of published articles through promotions

* Reduced timeline for article publication

Submit your articles and experience a new surge in publication services (https://www.peertechz.com/submission).

Peertechz journals wishes everlasting success in your every endeavours. 